\title{
RESEARCH ARTICLE \\ Anadolu Mandalarının PPARGC1A geninin 8. eksonundaki polimorfizmlerin belirlenmesi
}

\author{
Yasemin ALYÖRÜK ${ }^{1}$, Metin ERDOĞAN ${ }^{2 *}$ \\ ${ }^{1}$ Afyon Kocatepe Üniversitesi, Sağlık Bilimleri Enstitüsü, Afyonkarahisar, Türkiye \\ ${ }^{2}$ Afyon Kocatepe Üniversitesi, Veteriner Fakültesi, M. Biyoloji ve Genetik Anabilim Dalı, Afyonkarahisar, Türkiye \\ Geliş: 20.12.2018, Kabul: 13.02.2018 \\ *erdogan@aku.edu.tr

\section{Determination of the polymorphisms in the 8. exon of PPARGC1A gene of Anatolian Water Buffaloes}

\author{
Eurasian J Vet Sci, 2018, 34, 1, 13-18 \\ DOI:10.15312/EurasianJVetSci.2018.174
}

Öz

\begin{abstract}
Amaç: PPARGC1A geni glikoz-yağ metabolizması ve enerji dengesinde önemli bir role sahiptir. Ayrıca, çiftlik hayvanlarında süt kalitesi ve süt veriminde aday gen olarak kullanabilmektedir. Bu amaçla, Anadolu Mandalarında PPARGC1A geninin 8. eksonundaki polimorfizmler araştırılmıştır.
\end{abstract}

Gereç ve Yöntem: Araștırmada, Afyonkarahisar ilinde yetiștirilen ve "Anadolu Mandalarının Halk Elinde Islahı" projesi kapsamındaki 183 baş dişi malak incelenmiştir. PPARGC1A gen bölgesinin 8. eksonu ile 9. intronu arasındaki 739 bp büyüklügündeki bölüm ABI 3500 DNA dizileme cihazı ile araştııılmışıı. İstatistik analizlerde GENETIX paket programı kullanılmıștır.

Bulgular: PPARGC1A gen bölgesinin 8. eksonu ile 9. intronu arasındaki 739 bp büyüklüğündeki bölüm çoğaltılmış ve 8. eksonuna ait olan 526 bp lik kısmı değerlendirilmeye alınmıştır. Araştırmada, PPARGC1A geninin 8. eksonunda c.1598 A>T polimorfizmi gözlenmiştir. Yapılan Khi-kare $(\chi 2)$ analiz sonucunda popülasyonun HardyWeinberg dengesinde olmadığı, gözlenen ve beklenen değerler arasındaki fark istatistiki açıdan önemli bulunmuştur $(\mathrm{P}<0,001)$. A ve $T$ allelinin frekansı sırasıyla 0,768 ve 0,232 tahmin edilmiştir. İncelenen popülasyonda heterozigotluk $\% 24,59$ olarak hesaplanmıştır.

Öneri: Sonuç olarak, PPARGC1A geninin 8. eksonundaki c.1598 A>T polimorfizmi amino asit dizilimini etkilemektedir. Dolayısıly, GAC kodonu Aspartik asiti (Asp), GTC kodonu ise Valin (Val) amino asidini kodladığı için proteinin yapısı ve fonksiyonunun değişebileceği düșünülmektedir. Bu nedenle, c.1598 A>T ve gendeki diğer SNP'lerin büyüme, laktasyonun başlaması ve sürdürülmesi, süt verimi, sütün kalitesi ve sütteki yağ miktarı üzerine etkisinin araştırılarak, sonuçların Anadolu Mandası ıslah çalışmalarında kullanılabileceği düşünülmektedir.

Anahtar kelimeler: Anadolu Mandası, PPARGC1A, Polimorfizm, SNP
Abstract

Aim: PPARGC1A gene has an important role in glucose-lipid metabolism and energy balance. Also, PPARGC1A gene can be used as a candidate gene at milk quality and production at livestock animal. Therefore, this research has been conducted to determine the polymorphisms on 8. exon of PPARGC1A in Anatolian water buffaloes.

Materials and Methods: The total of 183 blood samples taken from Anatolian water buffaloes bred in Afyonkarahisar city and the Anatolian Water Buffaloes in the frame of reclamation project by Animal Breeders were used as a research material in this study. ABI 3500 genetic analyzer was used to investigate the region of $739 \mathrm{bp}$ that from 8. exon to 9. intron of PPARGC1A gene. GENETIX computer program was used for statistics analyses.

Results: In this study, an SNP located at the c.1599A>T on the 8. exon of PPARGC1A gene was found. The population showed disagreement with expected Hardy-Weinberg balance by Chi-square $(\chi 2)$ analyses $(\mathrm{P}<0.001)$. Frequencies of $\mathrm{A}$ and $\mathrm{T}$ alleles were estimated 0.768 and 0.232 , respectively. Heterozigosities were calculated $24.59 \%$ in Anatolian water buffaloes population.

Conclusion: As a result, c.1598 A> T polymorphism in exon 8 of PPARGC1A gene can affect the amino acid sequence. Thus, the structure and function of the protein would change the GAC codon encodes Aspartic acid (Asp) and the GTC codon encodes Valin (Val) amino acid. Therefore, determining the effects of c.1598 $\mathrm{A}>\mathrm{T}$ and other SNPs in PPARGC1A gene on growth could have an effect on the initiation and maintenance of lactation, milk yield, quality of milk and milk fat in Anatolian Water Buffaloes.

Keywords: Anatolian Water Buffalo, PPARGC1A, Polymorphism, SNP 


\section{Giriş}

Mitokondriyal ve ekstra-mitokondriyal lipid metabolizmasında görev alan genlerin transkripsiyonlarının düzenlenmesinde bir grup nükleer reseptör rol oynamaktadır (Issemann ve Green 1990, Kliewer ve ark 2001). Peroksizom proliferatör aktive edici reseptörler (PPAR) olarak adlandırılan bu reseptörler çok farklı biyolojik olaylarda görev almaktadır. PPAR'lar, nükleer reseptör ailesinin bir alt grubunu oluşturmaktadır. Bu reseptörler, hücre içinde lokalize olmakta ve transkripsiyonunun düzenlenmesinde görev almaktadır (Kliewer ve ark 2001). Yağ asidi ve karbonhidrat metabolizmasını düzenleyen, diyetsel lipid sensörleridir. Ayrıca, aterosklerotik lezyonlarda yer alan hücrelerde PPAR'ların anti-inflamatuar etkileri de tanımlanmıştır (Marx ve ark 2004). Farklı dokularda alfa (PPAR $\alpha$ ), beta (PPAR $\beta$ ) ve gamma (PPAR $\gamma$ ) tipleri belirlenmiştir (Guillaume ve ark 2006).

Transkripsiyon faktörleri ile beraber çalışan ve transkripsiyon hızını artıran proteinler koaktivatör olarak adlandırılmaktadır. Peroksizom Proliferatör Aktive Edici Reseptör Gamma Koaktivatör-1 (PGC-1), ilk olarak PPAR $\gamma$ 'nın transkripsiyonel koaktivatörü olarak tanımlanmıștır (Knutti ve Kralli 2001). Kahverengi yağ dokusu, karaciğer, kalp, böbrek ve beyin gibi mitokondriden zengin dokularda fazla miktarda eksprese olmakta ve metabolik ihtiyaçlarla gelen sinyaller doğrultusunda ekspresyonu artmaktadır. Özellikle, soğuğa maruz kalınması ile kas ve kahverengi yağ dokusunda, açlıkta kalp dokusunda ve uzun fiziksel egzersiz sonrası kas dokuda ekspresyonunda artış gözlenmektedir. PGC-1'nın diğer nükleer reseptörlerle etkileşimi ligand-bağımlı olmasına rağmen PPAR $\gamma$ ile ligand-bağımsız olarak etkileşmektedir. Mitokondride biyogenezis, oksidatif fosforilasyon ve yağ asitleri oksidasyonu enzimlerinin indüklenmesinde rol almaktadır (Puigserver ve ark 1998).

Peroksizom Proliferatör Aktive Edici Reseptör Gamma Koaktivatör 1 Alfa (PPARGC1A) geni, glikoz-yağ metabolizması ve enerji dengesindeki önemli rolü nedeniyle süt sığırlarında laktasyon süresini de etkileyebilmektedir. Süt sığırlarında, PPARGC1A geninin süt sığırlarında laktasyonun başlaması ve sürdürülmesinde süt sığırlarında tarafından gereksinim duyulan potansiyel bir aracı olabileceği ifade edilmektedir (Weikard ve ark 2005). Hücresel enerji metabolizmasının düzenleyicisi olan PPARGC1A'nın birçok nükleer hormon reseptörü aktivitesinde, termogenesisde transkripsiyonel faktörlerle, adipogenesis ve glikogenesis ile etkileștiği gösterilmiştir. (Handschin ve Spiegelman 2006, Liang ve Ward 2006, Liu ve Lin 2011).

İnsanlar ve hayvanlarda yapılan çalışmalar PPARGC1A geninin, yağ metabolizması üzerine önemli bir rolünün olduğunu ortaya koymaktadır. İnsan PPARGC1A genindeki Gly482Ser polimorfizminin tip 2 diyabet gelişimi için risk faktörü oluşturduğu (Kunej ve ark 2004) ve insülin salınımını etkilediği gözlenmiștir (Müller ve ark 2003). Domuzlarda, PPARGC1A genindeki cys430ser polimorfizminin yağlı ve yağsız doku oluşumu ile ilişkili olduğu ve bununda et kalitesini etkileyen önemli faktörler arasında yer aldığı bildirilmiştir (Kunej ve ark 2005). Bu polimorfizmin etçi sığırlarda büyüme ve kas artışı üzerine bir etkisinin olmadığı gözlenmiştir (White ve ark 2007)

Sığırlarda bu genin, süt özelliklerini (Weikard ve ark 2005, Khatib ve ark 2007, Komisarek ve Dorynek 2009, Kowalewska-Uczak ve ark 2010), büyüme ve et kalitesini (Soria ve ark. 2009), süt yağ bileşimini (Komisarek ve Dorynek 2009, Schennink ve ark 2009) etkileyen aday bir gen olabileceği öne sürülmüştür.

PPARGC1A'nın memede yağ sentezi ile de ilişkili olduğu bildirilmiştir (Liang ve Ward 2006). Laktasyon sürecinde, meme dokusunda mitokondri sayısının ve büyüklügünün artması PPARGC1A'nın ekspresyonundaki artışı ile ilişkilendirilmiştir (Jones 1974). Sığırlarında PPARGC1A geninin 9. intronundaki c.1892+19 T>C polimorfizmin süt yağı verimi ile ilişkili olduğu gözlenmiştir (Weikard ve ark 2005, Schennink ve ark 2009, Kowalewska-Uczak ve ark 2010). Süt sığırlarında PPARGC1A'nin 8. eksonundaki c.1209T>C polimorfizminin süt yağı kalitesi ile ilişkili olduğu bildirilmiștir (Weikard ve ark 2005).

Mandalardaki PPARGC1A geni ile süt verimi arasındaki ilişkinin araştırıldığı bir çalışmada mandalara özel yeni SNP’ler tanımlanmıştır. Bu SNP’lerin mandalardaki süt kalitesi ve üretiminde belirleyici olarak kullanılabileceğini belirtilmiştir (Javed ve ark 2011). Mandalar ile yapılan bir diğer çalışmada, PPARGC1A geninin ırklar arasında yapısal olarak farklılıklara sahip olduğu ve bu değişimin süt içeriğindeki farklılıklarla ilişkili olabileceği bildirilmiștir (Kumar ve ark 2012).

Anadolu Mandalarında süt verimi, büyüme ve gelişme ile ilişkili gen arasındaki ilişkiyi belirlemeye yönelik az sayıda araştırmaya rastlanmıştır. Anadolu Mandalarında çevresel faktörler ve büyüme hormon reseptörü (GHR) genindeki polimorfizmin malaklarda büyüme eğrisi ve canlı ağırlık parametrelerine etkisini araştırmak amacıyla yapılan bir çalışmada, GHR geninin 10. eksonundaki üç SNP belirlenmiş ve bu SNP'ler ile büyüme ve canlı ağırlık artışı arasında ilişki olduğu bildirilmiştir (Çelikeloğlu ve ark 2015). Farklı bölge orijinli Anadolu Mandalarından oluşturulan bir sürüde yapılan bir başka araştırmada (Tekerli ve ark 2016), verim özellikleri, beden ölçüleri ve biyokimyasal polimorfizm yönünden ıslah olanakları karşılaştırmalı olarak incelenmiştir. Genetik araştırmaların genişletilmesinin süt verimini artırmaya katkısının olacağı kanısına varılmıştır.

PPARGC1A geninin glikoz-yağ metabolizması ve enerji dengesindeki önemli rolü, süt kalitesi ve süt veriminde aday gen olarak kullanılabilmesi nedeniyle, bu araştırmada Afyonkarahisar ilinde yetiștirilen Anadolu Mandalarında, PPARGC1A geninin 8. eksonundaki polimorfizmleri araştırılması amaçlanmıştır.

\section{Gereç ve Yöntem}

$\mathrm{Bu}$ araștırma, Afyon Kocatepe Üniversitesi Hayvan Deneyleri Yerel Etik Kurulunun 29.07.2013 tarih ve 364 sayılı izni ile 
yürütülmüştür. Araştırmada, Afyonkarahisar ilindeki "Anadolu Mandalarının Halk Elinde Islahı" projesi kapsamındaki 183 baş dişi malak kullanılmıştır. Malakların V. jugularis'lerinden alınan kan örnekleri kullanılarak çalışma materyali DNA'lar izole edilmiştir. DNA izolasyon, Boom ve ark (1990) tarafından önerilen yöntem modifiye edilerek ve spin kolon metodu kullanılarak gerçekleştirilmiştir. Primerlerin tasarımında FastPCR 6.1.2 beta (Kalender ve ark 2009) bilgisayar programı ve NCBI'dan elde edilen PPARGC1A gen dizisinden (GU066311.1) yararlanılarak ileri (forward) primer 5'-AGCTCCATGACTCCAGACAA-3' ile geri (reverse) primer 5'-CAACAATCTCCTTAGTTCCGGGAA-3' tasarlanmıștır. PCR karıșımı için 2,5 $\mu \mathrm{l}$ 10xPCR buffer, $2 \mu \mathrm{l} \mathrm{MgCl2}$ (25 mmol), 0,5 $\mu \mathrm{l}$ dNTP karışımı (10 mM), 0,5 $\mu \mathrm{l}$ forward ve 0,5 $\mu \mathrm{l}$ reverse (10 pmol), 0,125 $\mu \mathrm{l}$ Platinium Taq polimeraz ve $2 \mu \mathrm{l}$ DNA (15-20 ng/ $\mu \mathrm{l})$ koyularak toplam hacim ultra distile su ile $25 \mu l^{\prime}$ ye tamamlanmıștır. PCR cihazı, önce $94^{\circ} \mathrm{C}$ 'de $2 \mathrm{dk}$, sonra $94{ }^{\circ} \mathrm{C}$ 'de $30 \mathrm{sn}, 56{ }^{\circ} \mathrm{C}$ 'de 30 sn ve $72{ }^{\circ} \mathrm{C}$ 'de $1 \mathrm{dk}$ olacak șekilde 35 döngü, $72{ }^{\circ} \mathrm{C}$ 'de $10 \mathrm{dk}$ ve $4{ }^{\circ} \mathrm{C}$ 'de bekletilecek şekilde programlanmıştır. Elde edilen PCR ürünleri, RedSafe (Intron, 21141)

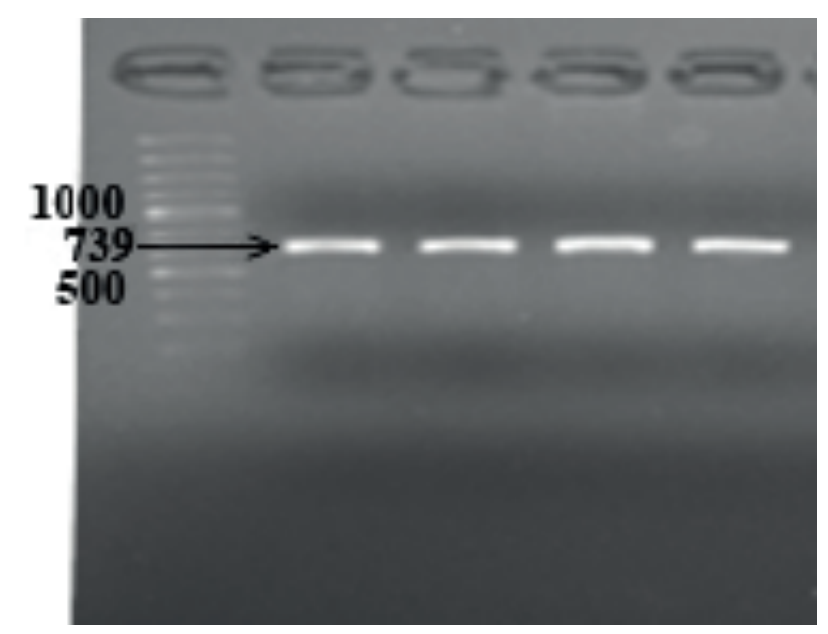

Resim 1. PCR ürünü jel görüntüsü
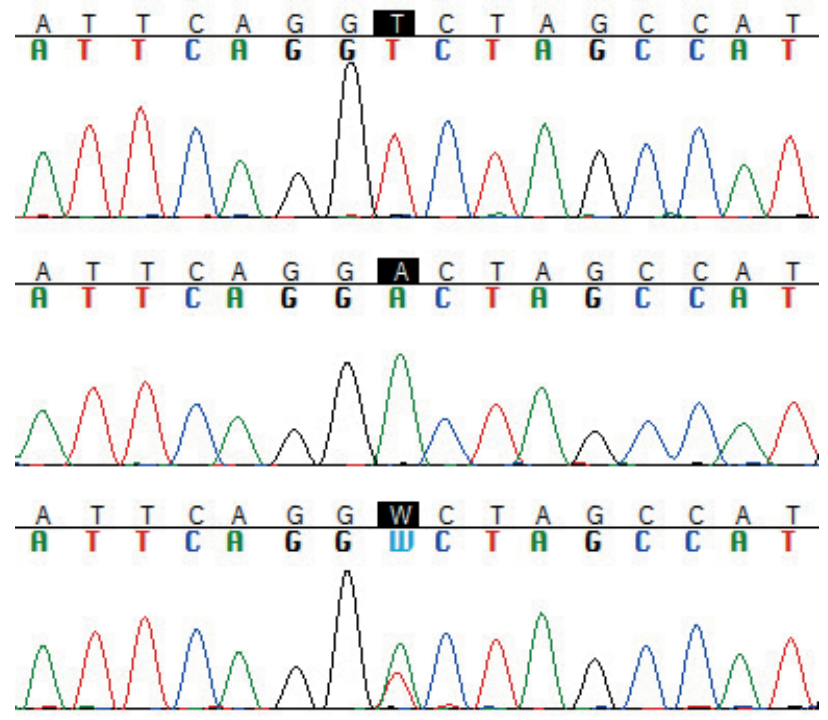

Şekil 1. PPARGC1A geninin 8. eksonunda gözlenen c.1598 A>T polimorfizmi ilave edilmiş \%2'lik agaroz jelde yürütülmüştür (Şekil 1). Daha sonra PCR örnekleri Ekzonükleaz I (Thermo, EN0581) ve FastAP (Thermo, EF0654) kullanarak temizlenmiștir. DNA dizileme PCR'ı için 12,0 $\mu \mathrm{l}$ 1xSequencing buffer, $2 \mu$ l BigDye, F veya $\mathrm{R}$ primeri (5pmol) ve $1 \mu \mathrm{l}$ temizlenmiş PCR ürünü karıştırılmıștır. Hazırlanan bu karışım PCR cihazına yüklenmiş ve PCR cihazı 96 ${ }^{\circ} \mathrm{C}$ 'de $2 \mathrm{dk}$ ve $96^{\circ} \mathrm{C}^{\prime}$ de $10 \mathrm{sn}, 55^{\circ} \mathrm{C}^{\prime}$ de 15 sn ve $60{ }^{\circ} \mathrm{C}$ 'de $4 \mathrm{dk}$ 35 döngü olacak şekilde programlanmıștır. Sekans PCR ürünleri etanol/EDTA protokolüne göre temizlenmiş ve her örnek için $15 \mu \mathrm{L}$ Hi-Di formamide eklenerek ABI 3500 Genetic Analyser cihazına yüklenmiştir.

DNA dizileme cihazından alınan forward ve revers dizileri Sequencher 5.4.1 (GeneCode) bilgisayar programında eşleștirilerek düzenlenmiştir. Daha sonra her bir örneğe ait sonuçlar BioEdit 7.2.0 bilgisayar programı (Hall 1999) yardımıyla değerlendirilip polimorfik bölgeler belirlenmiştir. Çalışılan gendeki allel frekansları (Xi), heterozigotluk (Ho), beklenen ve gözlenen genotip frekansları (Nei 1972) GENETIX 4.05.2 bilgisayar programı yardımıyla hesaplanmıştır.

Bulgular

PPARGC1A gen bölgesinin 8. eksonu ile 9. intronu arasındaki 739 bp büyüklügündeki bölüm çoğaltılmış ve agaroz jel elektroforeziyle UV ışık altında görüntülenmiștir (Resim 1).

DNA dizilime analizi sonucu 739 bp'lik PCR ürünlerinin 650 bp'lik bölümü sorunsuz okunabilmiştir. PPARGC1A geninin 8 . eksonuna ait olan 526 bp lik kısmı değerlendirilmeye alınmıştır. Araştırmada, PPARGC1A geninin 8. eksonunda c.1598 A>T polimorfizmi gözlenmiștir (Şekil 1). Protein sentezinde GAC kodonu aspartik asiti (Asp), GTC kodonu ise valin (Val) amino asidini kodlamaktadır.

PPARGC1A geninin 8. eksonundaki allel frekansları ve heterozigotluk indeksi Tablo 1'de verilmiştir.

İncelen mandaların PPARGC1A genindeki c.1598 pozisyonundaki A allel frekansının, T allel frekansına göre daha yüksek olduğu görülmüştür.

Yapılan Khi-kare $(\chi 2)$ analiz sonucunda incelenen popülasyonun Hardy-Weinberg dengesinde olmadığı, gözlenen ve beklenen değerler arasındaki farklar istatistiki açıdan önemli bulunmuştur $(\mathrm{P}<0,001)$.

Farklı hayvan türlerinde PPARCC1A geninin 8. eksonunun bir bölümündeki polimorfizm Şekil 2'de verilmiștir.

\section{Tartışma}

Kromozomal pozisyonu, enerji, yağ ve glikoz metabolizmasındaki anahtar rolü nedeniyle PPARGC1A geninin süt verimi ve sütteki yağ miktarı üzerine etkili olduğu bildirilmektedir. Bu nedenle, PPARGC1A geninin ineklerde laktasyonun başlaması ve 
Tablo 1. Anadolu Mandalarında PPARCC1A geninin 8.eksonundaki fenotiplerin dağılımı, allel frekansları ve heterozigotluk (Ho)

\begin{tabular}{lccccc}
\hline Genotip & Gözlenen & Beklenen & Allel & Frekans & Ho (\%) \\
\hline AA & 118 & 107,9 & A & 0,768 & \\
AT & 45 & 65,3 & T & 0,232 & 24,59 \\
TT & 20 & 9,9 & & & \\
\hline
\end{tabular}

${ }^{* * *} \mathrm{P}<0,001$

sürdürülmesinde, süt kalitesi ve miktarında artışa, hızlı büyümede etkili aday bir gen olabileceği düşünülmektedir (Weikard ve ark 2005).

Weikard ve ark (2005), Alman Holştayn'larında PPARGC1A geninin intron 9 bölgesinde c. $1892+19$ T $>C$ polimorfizmini belirlemişler ve bunun süt miktarında artışa neden olduğunu ileri sürmüşlerdir. Khatib ve ark (2007) ise Amerikan Holștayn'larında yaptıkları araștırmada aynı gen bölgesindeki SNP'nin süt verimini ve sütteki yağ oranını etkilemediğini bildirmişlerdir. Schennink ve ark (2009), Alman Holştayn'larında yaptıkları çalıșmada PPARGC1A genin intron 8 bölgesinde c.1790+514G>A polimorfizminin süt kalitesi ile ilişkili olduğunu belirlemişlerdir.

Mandalarda PPARGC1A geni üzerine yapılan sınırlı sayıda çalışma bulunmaktadır. Javed ve ark (2011), mandalarda PPARGC1A geni üzerine yaptıkları çalışmada, bu gende 6 adet SNP tanımlanmıștır. Bu SNP'lerin intron 3'de C718T, ekson 6'da A1844G, intron 6'da C1902T, ekson 8'de G2382T, C2529T ve A2657G pozisyonlarında olduğunu belirlemişlerdir. Bu SNP'ler amino asit zincirinde değișikliğe neden olmakta, dolayısıyla protein yapı- sını ve fonksiyonunu değiștirdiği, bu nedenle de tespit edilen SNP'lerin mandalarda süt kalitesi, süt verimi ve süt yağı oranıyla ilişkili olabileceği bildirilmiştir (Javed ve ark 2011).

Bu çalışmada, Afyonkarahisar koşullarında yetiştirilen olan 183 baş malağın PPARGC1A geninin 8. eksonunun bir bölümündeki polimorfizmin incelenmiş ve c.1598 A>T polimorfizmi belirlenmiştir. Bu polimorfizmin Javed ve ark (2011) belirledikleri SNP'den farklı olduğu görülmüştür. Tespit edilen polimorfizm amino asit dizilişinde değişikliğe neden olduğu için mandalardaki süt veriminin, süt kalitesinin ve sütteki yağ miktarının belirlenmesinde etkili olabileceği düșünülmektedir.

\section{Öneriler}

Sonuç olarak, PPARGC1A geninin 8. eksonundaki polimorfizmlerin belirlenmesi için amacıyla yapılan bu çalışma sonucunda bir SNP (c.1598 A>T) bulunmuştur. Bu SNP amino asit dizilimini etkilemekte, dolayısıyla protein yapı ve fonksiyonunun değișmesine neden olabileceği düşünülmektedir. Anadolu Mandalarında belirlenen bu SNP'nin ve gendeki diğer SNP'lerin büyüme,
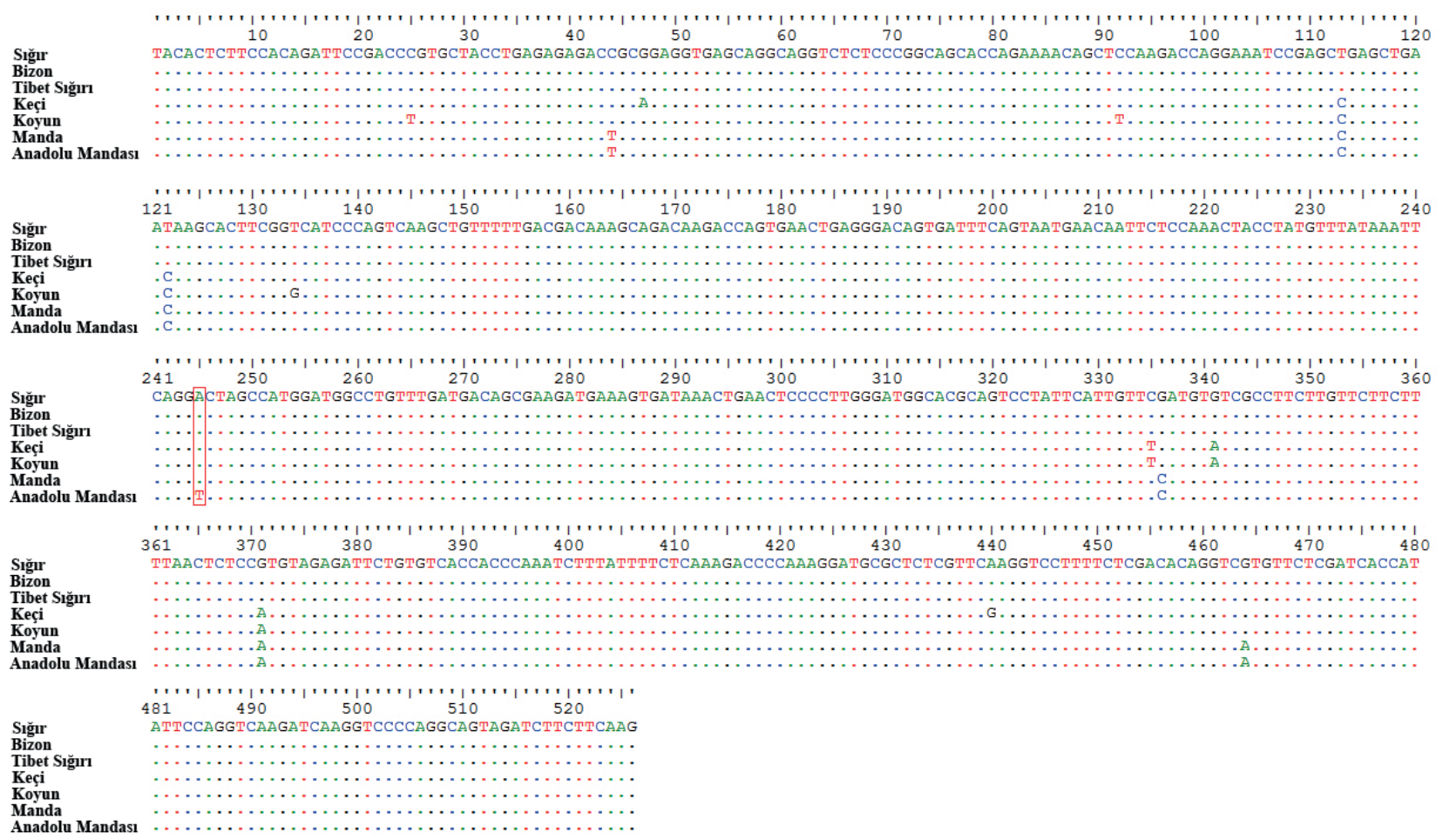

Şekil 2. Hayvan türlerinde PPARCC1A geninin 8. eksonunun bir bölümündeki polimorfizm 
laktasyonun başlaması ve sürdürülmesi, süt verimi, sütün kalitesi ve sütteki yağ miktarı üzerine etkisinin araștırılarak, mandalarda yapılmakta olan seleksiyon çalışmalarında kullanılabilme potansiyeli araștırılmalıdır.

\section{Teşekkür}

Bu araştırma, Afyon Kocatepe Üniversitesi Bilimsel Araştırma Projeleri Koordinasyon Birimi tarafından 13.SAĞ.BİL.20 proje numarası ile desteklenmiş ve Yasemin ALYÖRÜK'ün "Anadolu Mandalarında Peroksizom Proliferatör Aktive Edici ReseptörKoaktivatör 1 Alfa (PPARGC1A) Genindeki Polimorfizmin Belirlenmesi" isimli Yüksek lisans tezinin yayına hazırlanmış halidir.

\section{Kaynaklar}

Boom R, Sol CJ, Salimans MM, Jansen CL,Wertheim-Van Dillen PM, Van Der Noordaa J, 1990. Rapid and simple method for purification of nucleic acids. J Clin Microbiol, 28, 495-503.

Çelikeloğlu K, Erdoğan M, Koçak S, Zemheri F, Tekerli M, 2015. The effect of environmental factors and Growth Hormone Receptor gene polymorphism on growth curve and live weight parameters in buffalo calves. Lalahan Hay Arașt Enst Derg, 55(2), 45-49.

Guillaume I, Walter W, Liliane M, 2006. Functions of the peroxisome proliferator-activated receptor (PPAR) $\alpha$ and $\beta$ in skin homeostasis, epithelial repair, and morphogenesis. Journal of Investigative Dermatology Symposium Proceedings, 11 (1), 30-35.

Hall TA, 1999. BioEdit: A user-friendly biological sequence alignment editor and analysis program for Windows 95/98/NT. Nucl Acids Symp Ser, 41, 95-98.

Handschin C, Spiegelman BM, 2006. Peroxisome proliferator-activated receptor gamma coactivator 1 coactivators, energy homeostasis, and metabolism. Endocr Rev, 27, 728-735.

Issemann I, Green S, 1990. Activation of a member of the steroid hormone receptor super family by peroxisome proliferators. Nature, 347(6294), 645-650.

Javed R, Gautam SK, Vijh And RK, Tantia MS, 2011. Six novel PCR- RFLP loci in milk quality candidate genes in Bubalus bubalis. International Journal of Livestock Production, 2(6), 79-83.

Jones DH, 1974. The mitochondria of the mammary parenchymal cell in relation to pregnancy-lactation cycle, in lactation: A comprehensive treatise, Ed; Larson BL, Smith VR, Volume 4, Academic Press, New York, USA, pp: 503-512.

Kalendar R, Lee D, Schulman AH, 2009. FastPCR software for PCR primer and probe design and repeat search. genes, Genomes and Genomics, 3(1), 1-14.

Khatib H, Zaitoun I, Wiebelhaus-Finger J, Chang YM, Rosa GJ, 2007. The association of bovine PPARGC1A and opn genes with milk composition in two independent Holstein cattle populations. Journal of Dairy Science, 90, 2966-2670.

Kliewer SA, Xu HE, Lambert MH, Willson TM, 2001. Peroxiso- me proliferator activated receptors: from genes to physiology. Recent Prog Horm Res, 56, 239-263.

Knutti D, Kralli A, 2001. PGC-l, a versatile coactivator. Trends Endocrinol Metab, 12, 360-365.

Komisarek J, Dorynek Z, 2009. Effect of ABCG2, PPARGC1A, OLR1 and SCD1 gene polymorphism on estimated breeding values for functional and production traits in Polish Holstein-Friesian bulls. J Appl Genet, 50(2), 125-132.

Kowalewska-Luczak I, Kulig H, Kmieae M, 2010. Associations between the bovine PPARGC1A gene and milk production traits. Czech J Anim Sci, 55, 195-199.

Kumar A, Kumar R, Beniwal V, Kala SN, Mishra A, Raut AA, Naik PK, Chhokar V, 2012. Molecular differentiation of peroxisome proliferator activated receptor coactivator-1 among different breeds of Bubalus bubalis. Bioinformation, 8(13), 600-606.

Kunej T, Globocnik Petrovic M, Dovc P, Peterlin B, Petrovic D, 2004. A Gly482Ser polymorphism of the peroxisome proliferator-activated receptor-g coactivator-1 (PGC-1) gene is associated with type 2 diabetes in Caucasians. Folia Biol, 50,157-158.

Kunej T, Wu XL, Berlic TM, Michal JJ, Jiang Z, Dovc P, 2005. Frequency distribution of a Cys430ser polymorphism in peroxisome proliferators-activated receptor gamma coactivator-1 (PPARGC1A) gene sequence in Chinese and Western pig breeds. J Anim Breed Genet, 122, 7-11.

Liang H, Ward WF, 2006. PGC-1 alpha: A key regulator of energy metabolism. Adv Physiol Educ, 30(4), 145-151.

Liu C, Lin JD, 2011. PGC-1 coactivators in the control of energy metabolism. Acta Biochim Biophys Sin, 43, 248-257.

Marx N, Duez H, Fruchart JC, Staels B, 2004. Peroxisome proliferator activated receptors and atherogenesis: regulators of gene expression in vascular cells. Circ Res, 94, 11681178 .

Muller YL, Bogardus C, Pedersen O, Baier L, 2003. A Gly482Ser missense mutation in the peroxisome proliferator-activated receptor g coactivator- 1 is associated with altered lipid oxidation and early insulin secretion in Pima Indians. Diabetes, 52 , 895-898.

Nei M, 1972. Genetic distance between populations. Am Nat, 106, 283-292.

Puigserver P, Wu Z, Park CW, Graves R, Wright M, Spiegelman $\mathrm{BM}, 1998$. A cold inducible coactivator of nuclear receptors linked to adaptive thermogenesis. Cell, 92, 829-839.

Schennink A, Bovenhuis H, Leon-Kloosterziel KM, Arendonk M, Visker W, 2009. Effect of polymorphisms in the FASN, OLR1, PPARGC1A, PRL and STAT5A genes on bovine milkfat composition. Anim Genet, 40, 909-916.

Soria LA, Corva PM, Branda Sica A, Villarreal EL, Melucci LM, Mezzadra CA, Papaleo Mazzucco J, Fernández Macedo G, Silvestro C, Schor A, Miquel MC, 2009. Association of a novel polymorphism in the bovine PPARGC1A gene with growth, slaughter and meat quality traits in Brangus steers. Mol Cell Probes, 23, 304-308.

Tekerli M, Altuntaş A, Birdane F, Sarımehmetoğlu O, Doğan I, Bozkurt Z, Erdoğan M, Çelik HA, Koçak S, Gürler Z, Bülbül T, Kabu M, Çelikeloğlu K, 2016. Farklı bölge orijinli Anado- 
